\title{
The Judges and the Vigilant State \\ A.W.B.Simpson*
}

The title of this paper needs a little explanation. When I was approached on the possibility of giving it, I was kindly given a free hand in the choice of a subject, which could be related to any research I was doing, so long as this could, in some way or other, be related to the Glorious Revolution, and the Bill of Rights of 1689 . Now for some time I have been doing research into the detention of British citizens without trial under Regulation 18B of the Defence Regulations during the 1939-45 war. Indeed I used some of this research for a Child lecture I gave in Oxford in $1987 .{ }^{1}$ Of course I could not simply repeat this lecture, but it seemed to me that other parts of the material I have so far unearthed might be related to the required theme of this paper. Let me try to explain how.

Outside Ulster the Glorious Revolution of $1688-89$, and the constitutional settlement which followed upon it, has long ceased to have any emotional hold on the British people generally, or on lawyers in particular. I should be surprised if many people in this room have, in the last ten years, if indeed ever, actually read in full the three constitutional documents which it generated: the Heads of Grievances of 2 February 1689, the Declaration of Right of 12 February $^{2}$ and the Bill of Rights itself. ${ }^{3}$ Let me assume that at least some of you are a little rusty on the matter, and simply quote to you a vision of what happened from a popular though scholarly book on the subject, written by G. M. Trevelyan, and first published in 1938:

James II attempted to make the law alterable wholesale by the King. This, if it had been permitted, must have made the King supreme over Parliament and, in fact, a despot. The events of the winter of $1688-9$ gave the victory to the opposite idea, which Chief Justice Coke and Selden had enunciated early in the century, that the King was the chief servant of the law, and not its master;

*Professor of Law at the University of Michigan. The Child \& Co.. Lecture 1989, printed by arrangement with Professor Simpson and Child \& Co.

1. Published as "Rhetoric, Reality, and Regulation 18B," and now available in the 1988 Denning Law Foumal.

2. Presented the following day.

3. 1 W. \& M. sess. 2 c.2. See also L. G. Schwoerer, The Declaration of Rights, 1689 (Baltimore, 1981). Appendix 1 gives the text of the Declaration and the reply of 15 February. Dates given here are in old style. 
the executant of the law, not its source; the laws could only be altered by Parliament - King, Lords and Commons - together. It is this that made the Revolution the decisive event in the history of the English constitution. It was decisive because it was never undone, as most of the changes of the Cromwellian Revolution had been undone. ${ }^{4}$

So there it is - a permanent triumph for the rule of law and the sovereignty of Parliament over the King, and the end of the threat of despotism. Now of course since those days the personal powers of the Monarch have diminished, and we now have a Prime Minister who, no doubt in a spirit of academic realism, affects from time to time the use of the Royal "we" herself. But in spite of this tasteless linguistic aberration we must recognise that the position once occupied by the Monarch has, in the intervening three centuries, been colonised not simply by the Prime Minister, but by what we call the executive - ministers, civil servants and officials of one kind and another, forming an army whose size and complexity was unimaginable to the lawyers and parliamentarians who forged the settlement of 1689. They range from Sir Humphrey and his likes to those equivalents of feudal barons, the chief constables, and down to the vigilant officers who riffle through one's underwear at Heathrow, officers soon, one hopes, to become largely redundant.

Now where do the judges fit into that settlement? By judges I do not mean judges like myself, a mere Justice of the Peace, but that narrow category once known as the twelve men in scarlet or the oracles of the law, and now hugely inflated to a current figure of well over a hundred. During the Glorious Revolution it was generally agreed that the independence of the judges needed to be safeguarded against removal from office at the pleasure of the Crown. But time was short, and legislation was needed to make what was a change in the law. This was not in fact done until the Act of Settlement of 1701. The job of the judges was to subject the cxecutive to the rule of law and preserve the supremacy of Parliament, and this not as an end in itself, but to protect liberty. The purpose of judicial independence was the protection of English liberty. Let me quote you what Blackstone said about it. ${ }^{5}$

In this distinct and separate existence of the judicial power in a peculiar body of men, nominated indeed, but not removeable at pleasure, by the crown, consists one main preservative of the public liberty ... Nothing therefore is more to be avoided, in a free constitution, than uniting the power of a judge with a minister of state.

4. G. M. Trevelyan, The English Revolution (Home University Library edition), at p. 165. Generally see M. Landon, The Triumph of the Laxyers: Their Role in English Politics 1678-1689 (University of Alabama Press, 1970). See also W. A. Speck, Reluctant Revolutionaries: Englishmen and the Revolution of 1688 (Oxford 1985).

5. Commentaries I, 269. 
Awful things, he explained, went on in Turkey because they had not grasped the importance of maintaining the distinct roles of judges and ministers, as was done in England.

Since 1701 only one rather downmarket judge, Sir Jonah Barrington, has actually been formally removed by the procedure which was then established, and the occasional individuals who, because of drink, senility or whatever, have needed to be eased out of office have been given the old "Heave Ho!" by informal means, or have conveniently died or destroyed themselves. It is important however to appreciate that a tenured Judge who avoids the grosser forms of bad behaviour has, in a real sense, nothing to fear from the executive, not even loss of his job and the generous pension which goes with it, much less anything more unpleasant, even though he reaches decisions which the executive does not like.

There is however one important exception which has developed since 1701, and this exception may be important. It is loss of promotion. Given the increase in the number of the oracles of the law the system has evolved so as to deprive those who have not made it to the Court of Appeal or above of most of their oracular status. In consequence promotion is valued in a way which was not true in the past. It operates as a pressure to conformity. Formal judicial independence does not of course free judges from such pressure; indeed without it it is hard to see how we could have law at all. Let me give two examples of the operation of such pressure. Once, as magistrate, I and a colleague awarded costs against the police - in retrospect perhaps wrongly. They did not like this, and for some months I found myself sitting exclusively in the fine defaulters' court, far from where the real action was. When I complained I was told it was just chance, but I was not convinced. My second example comes from John Mortimer - apparently the Old Bailey judges ate and perhaps still do eat their lunch wearing their wigs. No sane person would engage in such insanitary and aesthetically repulsive behaviour unless peer pressure to conformity was very powerful indeed.

Now formal judicial independence - freedom from the sack, freedom from suit and freedom from grosser forms of pressure such as massive reduction of salary is something essentially negative. I think there is more to the conception of judicial independence than this. Judicial independence also involves the idea that the judiciary should, through their decisions, function as a distinct force in government. By doing so they will both operate as a check or restraint upon the executive, and make their own contribution to the business of government by championing the virtues associated with the ideal of the rule of law or, as Dicey once called it, the predominance of the legal spirit. These virtues include such notions as the notion of a fair trial, of access to the law, of openly administered justice, of rational decisions in conformity with professional tradition, of the voluntary character of criminal offences, and so forth. To be sure judges can only administer "the law", but the law embodies much leeway and these virtues are in any event part of it. To be sure too Parliament may legislate in ways which are incompatible with them, but a judge who understands positive independence will 
have a strong presumption that this has not been the intention. The effectiveness of the judiciary in discharging their functions in the constitutional scheme established by the Glorious Revolution will depend to a considerable degree on the status of the judiciary, and their distinction from the executive as "a peculiar body of men" and now women, a point to which I shall return.

Now let me tell you something about the rise of the vigilant state - the state or the executive when it is engaged, or supposed to be engaged, in protecting us from espionage, terrorism and subversion. It does so in the name of liberty, but at the same time it is notorious that the apparatus involved threatens liberty, and notorious too that those involved in the business seem everywhere to engage in deceit and in illegal and criminal activity, on an uncertain scale. ${ }^{6}$ I take the expression "vigilant state" from the title of Dr. Bernard Porter's excellent book, The Origins of the Vigilant State: The London Metropolitan Special Branch before the First World War. ${ }^{7}$ Here he traces the formation of a separate division of the London police force to deal with subversion; the original special branch developed between 1881 and 1884 in response to the activities of the Fenians. Today all police forces have their special branches, membership of which carries with it considerable kudos, though the Metropolitan Special Branch is normally the one employed by the Security Service, whose officers are not constables. As Dr. Porter explains:

Ireland was the main cause of Britain's fall from liberal grace in the matter of counter-subversion. For very many years her people had displayed a propensity for politically motivated crimes of unusual savagery, either because it was in their character, as many Englishmen claimed, or because they were provoked into this by the nature of their relationship with the British government. $^{8}$

Curiously enough it was that great liberal, Sir William Vernon Harcourt, Home Secretary from 1880-1885, who not only fathered the Metropolitan Special Branch but rather fell in love with the sneaky world of agents, informers, and "tricky practices" with which we have become all too familiar. He has, I fear, been followed in this by others who should know better.

As the Fenian threat diminished, other dangers conveniently arose to ensure the continuance of Special Branch - for example anarchism, and homosexuality, the latter only too familiar to the governing elite from their schooldays. By 1914 Special Branch had swollen to 114 officers, a figure which rose to 700 by the end

6. The principal importance of Peter Wright's Spycatcher is that it has brought this into the open. In the proceedings in Australia the Crown was so nervous of specifying which of the many acts of illegality listed had occurred that it simply conceded the lot, claiming that this was simply done for the purposes of the litigation. It was hoped that this evasive technique would keep egg off the shirts of those involved. Nobody was taken in.

7. London (1987).

8. At p. 26. 
of the war. ${ }^{9}$ By then further perils had been constructed. A phantom army of German spies and saboteurs were thought to infest the land, a belief linked to characteristic British zenophobia. It has been argued with considerable plausibility that the fears of this period were much fuelled by a growing literature of spy stories. You will recall no doubt Erskine Childer's Riddle of the Sands, first published in 1903, a distinguished example of this genre, written not just for fun, but to convey a message.

More influential were the ludicrous writings of William Tufnell le Queux, an individual unable to distinguish fact from fiction. ${ }^{10}$ His works fill seventeen columns in the printed British Library catalogue, which is by no means complete, ${ }^{11}$ and include such titles as The Indiscretions of a Lady's Maid. Being Some Strange Stories Related by Mademoiselle Le Bas, Femme de Chambre and The Confessions of a Ladies Man. Being the Adventures of Cuthbert Broom of His Majesty's Diplomatic Service. The story he put about was that he only wrote novels to finance his work as a sort of freelance spy. He was most proud of the influential The Invasion of 1910 , published in $1906^{12}$ with an introductory letter from no less than Field Marshal Earl Roberts of Kandahar. Le Queux claimed to have obtained a copy of a secret speech by the Kaiser stating his intention to conquer Britain with zeppelins; it contained this memorable and chilling passage:

Do you remember, my Generals, what our never-to-be-forgotten Field Marshal Gebhard Leberecht von Blücher exclaimed, when looking from the dome of St. Paul's Cathedral upon the vast metropolis at his feet? It was short and to the point. "What a splendid city to sack!"

In 1909 all this led to the establishment of the Secret Service Bureau - the ancestor of what is now called MI5, though its proper title, insofar as it is possible to say, is the Security Service. ${ }^{13}$ The turning point is said to have been an incident which took place in the home of a very disreputable Mayor of Canterbury, one Frank Bennett-Goldney, M.P., Athlone Pursuivant, suspected by some of having

9. Porter, supra n.7, p. 114.

10. 1864-1927. His entry in Who's Who noted as a hobby the appropriate "revolver practice". There is a life by Norman St. B. Sladen, published as The Real Le Quetux. The Official Biography of William Le Queux (London, 1938). The flavour of this work and of Le Queux's idiocies is caught by an account of a chance meeting between Le Queux and an elderly and ill British traveller, one Charles Askew, in the hotel Marenta in Mostar; he was "a studious man, a nature lover and a botanist, and he knew a great deal about wild birds". He also owned a battered tin box. Le Queux's suspicions were at once aroused: "Le Queux wondered if he were a crook in hiding; if so, what better district than Herzegovina?". He turned out to be one of America's most famous multi-millionaires.

11. According to his biographer he wrote over a hundred novels.

12. Originally serialised in The Daily Mail.

13. Probably between 1912 and 1940 the United Kingdom security service was conceived to be only one part of an Imperial Security Service, run from Britain and covering the whole Empire except India, which of course had its own service. This, at least, was the belief of Sir Eric Holt-Wilson, who was its Chief Staff Officer and deputy to Sir Vernon Kell. Presumably he knew. The whole subject is extremely murky, and all accounts of the structure of the service must be taken with caution. 
been involved in the theft of the Irish Crown jewels in $1907 .{ }^{14}$ The victim of what appears to have been a practical joke, he thought he had found two German spies in the garden, and convinced the Secretary of State for War, J. B. S. Haldane, of the threat. ${ }^{15}$ You may, if you wish, enjoy a pint of ale where it all happened, in the garden of what is now the Abbots Barton Hotel. ${ }^{16}$ Be the story correct or not MI5 had by July of 1914 expanded modestly to fourteen officers and staff, and has since then flourished mightily. By the end of the war it comprised 844 persons; by 1915 its work was assisted by, amongst others, the 1,453 persons staffing the postal censorship, and numerous others censoring telegrams.

Hand in hand with this increase in the numbers of persons engaged in counter-subversion was the development of a monstrous secret archive. Just as the Golden Stool of Ashanti was and indeed is conceived of as embodying the soul of the Ashanti people, so the soul of counter intelligence resides in such an archive, and in recent times Peter Wright, or his ghost writer, has written feelingly of the religious awe which surrounded the Registry of MI5 in his time, and no doubt still does today, where nicely brought up young ladies known as the Registry Queens attend upon it. ${ }^{17}$

It all began before the first war when the chief threat was thought to come from German spies recruited from the resident alien population. So between 1910 and 1913 Winston Churchill, then Home Secretary, established, without Parliamentary authority, a secret Aliens Register, and during the first war this expanded from 30,000 to 99,500 entries to include the names of 53,000 aliens, 12,000 women married to aliens, and - and this is typical of the paranoid mentality of those involved - no less than 34,500 British nationals suspected of having enemy blood. ${ }^{18}$ Naturally enough the institutions of the vigilant state were somewhat cut back in the inter-war years, and the focus of anxiety shifted towards bolshevism, pacifism, and in due course fascism. But the archive, like some obscene fungal growth which flourishes in darkness, continued to swell. So too did the collection of aliens' files held by the Home Office, and the archives of Special Branch.

14. For an account of this individual's activities see, F. Bamford and V. Bankes, Vicious Circle (London, 1965).

15. The story is told by C. Andrew, Secret Service, p. 34.

16. As you enter this hostelry you may notice a door handle in the form of an elephant; the house (as Westfield House) was originally the home of a general, Sir David Russell (1809-1884), who had seen service in India, commanding the fifth brigade at the second relief of Lucknow. He apparently introduced the oriental plane tree to the city - one is still to be seen in the Cathedral Close, and one existed in the garden of his house which originally extended over the New Dover Road.

17. P. Wright, Spycalcher (paperback edition, New York, 1988), at p. 47 calls it "The nerve centre of MI5 ..." and describes the system in his time, that is from 1955. A card index on "Cope-Chatterton" cards was used to locate individual buff coloured Personal Files; there were also subject files, and what he calls duck egg blue List files.

18. A document apparently written by Sir Eric Holt-Wilson on his work in the Security Service says that by the outbreak of the war "he had compiled ... a Register with full biographical details of over thirty thousand aliens and others [my italics] who were considered potentially dangerous in the event of a war with Germany and her potential allies": National Archives RG 84 London Embassy Confidential file $711.2-8202 \mathrm{~B}$. 
A curious picture of the development of MI5 was provided in 1940 to officials in the U.S. Embassy in London by Brigadier Sir Eric Holt-Wilson, who had just retired as Chief of Staff and Deputy Director after twenty eight years work in the service, which he had joined in $1912 .{ }^{19}$ Sir Eric had been much involved in the drafting of parts of the Defence of the Realm Acts of the first war, and the regulations insofar as they dealt with counter-subversion, and he performed the same role in the early part of the second war; he had also claimed to have been the moving spirit behind the Official Secrets Act of 1920 . He had also apparently been in charge of the establishment of the Registry. In July of 1940 an American official in the U.S. Embassy, Mark Klemmer, briefed principally by Sir Eric, wrote a somewhat credulous memorandum on the Fifth Column in Britain and the steps being taken by MI5 to counter its activities. The belief in the myth of a Fifth Column was widely held at the time. He recorded: ${ }^{20}$

One of the major activities of the Security Service is the maintenance in London of a central index of suspicious persons. This index contains the names of every person ever suspected in any part of the world of anti-British activity - a total of 4,500,000 names. ${ }^{21}$ The index is freely used by British industry and government departments.

There were some 250-300 persons in the service, of whom 100 were "officials" (I suppose this means "desk" officers as opposed to secretaries, drivers, tea-ladies etc.). He became almost lyrical with admiration over the way in which the security service had been set up:

The English have done a very smart thing in connection with counterespionage, which might well be copied in the United States. Unknown to the British public, unknown to the newspapers, and unknown even to most of the government officials (he does not even mention Members of Parliament) there has been in existence in this country for 31 years an elaborate

19. In 1940 Sir Vernon Kell and Sir Eric lost their jobs. Kell was two years older than Sir Eric and thought of himself as sacked; his deputy conceived of himself as having merely retired.

20. The memorandum and supporting documents are in N.A. RG 84 London Embassy Confidential File 711.2-8202B. These archives have been extensively weeded of documents originating from MI5. 21. The figure appears incredible, and the members of the Security Service who briefed Klemmer must have been trying to impress by dishonest exaggeration. To have reached this size in the course of twenty eight years 160,714 names would need, on average, to have been added annually (this would be from both Britain and the Empire) and I cannot believe that this happened. Peter Wright claims that when he joined the service in 1955 the number of personal files held was about two million, and if we assume that the cold war led to a considerable increase in numbers between 1945 and 1955 it would not be implausible to suppose that in 1940 the number might have been as high as a million. An uncertain number of personal files were destroyed by bombing in 1940. The numbering of personal files employed during the war employed five figure numbers - for example the journalist Claude Cockburn's file was PF 41685 , but this does not necessarily mean that the total number in the system was limited to five figures, since the figures may have been repeated for each letter of the alphabet, with a total capacity of $2,599,974$. 
organisation for the detection and prevention of the activities of foreign governments.

And later he added:

Officials of the Security Service tell me that the success of the organisation has been due primarily to the fact that they have operated in complete secrecy. They declare that no British newspaperman has ever discovered the true scope of the organization.

And so it was that Big Brother came to be able to watch us all, and although it is certainly the case that the vigilant state all began as an aspect of the Irish question, it was the conflicts with Germany which led to the consolidation of its apparatus, and the two wars of this century, particularly the second, which enabled the executive, in the course of less than a single day in 1939, to introduce, through Parliament, the machinery of totalitarian government in the form of the Emergency Powers Act and the two codes of regulations based upon it. As E. S. Turner put it:

To fight tyranny, it was essential to use many of the weapons of tyranny. Peace time luxuries like Habeas Corpus were tossed into the nearest Whitehall oubliette. So fast were new offences created that neither police nor lawyers could keep up with them. ${ }^{22}$

The whole scheme of totalitarian government had of course been in existence long before the war, its existence being concealed; no doubt the same is true today.

Now to be sure these powers were in fact exercised with considerable restraint. For example, in Britain during the 1939-45 war only $1,847^{23}$ British citizens were detained without trial under Regulation 18B of the Defence (General) Regulations; simplifying the matter somewhat people could be detained if they were of "hostile origins or associations", had been recently engaged in "acts prejudicial" or were supporters of the British Union of Fascists or had been. ${ }^{24}$ Many detainees, and probably most, were perfectly loyal people, and many quite harmless. It is impossible because of official hostility to the writing of history to form any quantitative estimate of the extent to which the power of detention was deliberately abused or employed with callous incompetence, but no doubt such

22. The Phoney War (London, 1961), p. 37. He added that "One day sufficed to turn Britain into a totalitarian state."

23. Perhaps slightly less; this was the number of orders actually made, and not all may have been implemented.

24. For a fuller account see my earlier lecture, supra n.1. The form of the Regulation was changed during the war, and in the form in which it existed in the summer of 1940 it was necessary for the Home Secretary to have reasonable cause to believe that the detainee fell into an appropriate category and that it was necessary to detain them. 
things happened. But it could have been very much worse. ${ }^{25}$ In America, where the immediacy of the military threat was dramatically less than it was in Britain in the summer of 1940, when most of these detentions took place, a vastly greater number of citizens of Japanese descent, whole families of them, were detained after Pearl Harbour and kept in detention long after any conceivable justification had disappeared. The whole unsavoury business was strongly affected by racialism; because of American attitudes to freedom of information we now know more about the disreputable conduct of some of those involved than we know of the British experience. ${ }^{26}$ There was much greater restraint in Britain, and there are many different reasons for this - for example I am told that Sir Alexander Maxwell, who was Permanent Under Secretary at the Home Office during the war, used to deliver talks to his officials on the importance of preserving civil liberty.

In this paper I will confine myself to saying something about a much narrower issue - what part have the judges, through their decisions in court, played in exercising some control over the vigilant state? What have they done to ensure that its activities have been properly authorised by Parliament, or by some established principle of the common law, and, so far as possible, brought under the control of the rule of law and the virtues associated with that concept?

Recently we have had the Spycatcher affair, but being a historian I shall deal with rather earlier events into which I have looked, principally events in the wars. Now I do not think it would be either possible or sensible for me, in this paper, to catalogue the judicial decisions, awarding to some brownie points and to others forfeits, in an attempt to establish an index of judicial performance. However, I think that nobody could seriously claim that the general tendency of judicial decisions in this area has been at all favourable to the protection of the supremacy of Parliament, to the protection of the rule of law, or to the protection of civil liberty. Let me explain why I think that this rather large claim is justifiable.

In some areas of the law it is possible to point to a legal decision which possesses the status of a landmark. An example from 1772 is Somerset's Case ${ }^{27}$ with its immortal conclusion, probably never uttered, "let the black go free". No doubt you can think of many others; a modern American would of course instinctively think of Brown v. Board of Education, ${ }^{28}$ which rejected the notion that separate but equal was a constitutionally acceptable solution to the racial problems which the Civil War had failed to solve. Of course, it is true that revisionist history usually shows both that the practical effect of landmark decisions is either less than is generally

25. Without here going into details, in late 1940 MI5 suffered a defeat at the hands of the Home Office.

26. For a comparison, see my "Detention without Trial in the Second World War: Comparing the British and American Experiences", 16 Florida State University Lam Rev. 225 (1988). Similar excesses took place in Canada. There is an extensive literature on all this, and attempts to secure compensation and other forms of redress have enjoyed a limited degree of success.

27. 20 St. Tr. 1, decided 22 June 1772.

28. 347 U.S. 486 (1954). 
believed, or rather different from what was expected at the time; thus the result of Somerset's Case was not that all the slaves in Britain went free. ${ }^{29}$ It is also generally the case that such decisions are not isolated paradigm shifts, but part of a process of change. But for all that they have both a practical and symbolic importance; if they do not cause change they signal it.

But what are the landmark decisions in our field? Well everyone would have their own list, but all would have to include the decisions of the House of Lords in March of 1917 in $R$. v. Halliday, Ex parte Zadig ${ }^{30}$ which upheld the validity of Regulation 14B of the Defence Regulations as within the powers conferred on the executive by the Defence of the Realm (Consolidation) Act of 1914, and Liversidge v. Anderson, decided by the House of Lords in November of 1941 at the same time as Greene v. Secretary of State for Home Affairs, ${ }^{31}$ which held that in the absence of fraud, error as to identity, and perhaps gross formal defect the courts had no jursidiction to exercise any form of supervisory control over the power of the Home Secretary to detain British citizens for indefinite periods, and this without charge, trial or term set. ${ }^{32}$ Who won in these cases? The vigilant state. And who lost? Two perfectly loyal British citizens, both released as soon as seemed decent once the actions had been lost. And for what are these decisions celebrated? Not for what they decided, but for what they did not decide, that is for the impassioned dissenting opinions of Lord Shaw of Dunfermline in 1917 and Lord Atkin in 1941. But they were dissenting. They lost. The executive won. And although I do not know of any evidence that Lord Shaw ${ }^{33}$ suffered any personal unpleasantness as a consequence of his opinion, we all know what happened to Lord Atkin, in whose honour this building is named. ${ }^{34}$

En passant may I take this chance to rescue from oblivion a third dissenting opinion, acidly contemptuous in tone rather than impassioned, delivered by Lord Justice Scrutton in Ex parte Brady. ${ }^{35}$ This case was one in which the Court of Appeal ruled that under the Restoration of Order in Ireland Regulations then in force - and now I quote from Lord Justice Scrutton:

\section{See F. O. Shyllon, Black Slaves in England (London, 1974).}

30. [1916] 1 K.B. 738; [1917] A.C. 260. The Lords decisions cited here are all discussed in R. Stevens, Law, and Politio: the House of Lords as a Fudicial Body 1800-1971.

31. [1942] A.C. 206, and (Greene's case) 284.

32. Amongst the things the courts could have done would have been to exercise a supervisory function over the procedures involved which favoured the liberty of the detainees (for example, by insisting on adequate statements of the reasons for detention), and to have shown some interest in the interpretation of the categories employed in the regulation. I say this only to make the point that there were middle grounds between the courts taking over the whole matter on the one hand, and effectively washing their hands of the matter on the other.

33. The distaste felt by some for Lord Shaw is brought out in Lord Macmillan's extremely hostile account of him in The Dictionary of National Biography. I cannot imagine that his Lordship's colleagues were pleased with the tone of his opinion in the Zadig case, which is if anyching more impassioned than Lord Atkin's in the Liversidge case.

34. See R. F. V. Heuston, Liversidge v. Anderson in Retrospect, 86 L.Q.R. 229 (1969).

35. Reported in 125 Law Times 344 and 126 Law Times 9. See also The Times, 26 June 1921. Documents on this case are in PRO TS 27/140. 
... it is possible to take any person, who like this boy has lived five years in England, to shut him up for an indefinite time without telling him the charge against him, without bringing him to trial, at the uncontrolled discretion of an officer of the executive. In my view' such a result would not follow unless the clearest words are used by Parliament. In this case Parliament has not used, in my opinion, clear words.

But his colleagues were not impressed, and so executive detention became legitimate throughout the whole United Kingdom. You will note that Lord Justice Scrutton is here, in the spirit of the Glorious Revolution, exercising his judicial independence to protect the rights of Parliament, and this was Lord Shaw's position in the case of Arthur Zadig. Well, we all know what happened to Lord Justice Scrutton, widely thought to have been the best commercial lawyer of his period; he never made it to the top, and it is said that his manner had something to do with this, though I know of no evidence which singles out this opinion as critical to his lack of promotion.

Now let us look at the matter in a slightly different way, and, reflecting on the growth of the vigilant state, enquire whether we can point to legal decisions in the regular courts which have in some way or other restrained its growth, curbed its activities, or rendered the activities of those involved in the work of surveillance accountable to Parliament or to the public. Well, at first glance one is inclined to say that there are no such cases to be found. Take trials in camera - somehow the latin makes it sound better than secret trials. Such trials are wholly incompatible with the ideal of the rule of law, and are normally associated with disagreeable "foreign" systems. Cases involving young persons apart, such trials were first explicitly ${ }^{36}$ authorised in times of peace by the Official Secrets Act of 1920, a boon conferred on the British public by Sir Eric Holt Wilson. The institution reached its high point I suppose in the trial of George Blake who was tried in camera in 1961 and sentenced to the record term of forty two years; this sentence at the time qualified for the record books. ${ }^{37}$ Blake prudently decamped to Russia and in consequence no conceivable public interest is involved in continued secrecy. Yet to this day no transcript of his trial is available. ${ }^{38}$ It is quite inconceivable that the executive could have resisted disclosure if the trial judge had insisted; he was after

36. A somewhat vague common law power existed to exclude the public or individuals if this was necessary in the interests of justice; some judges used to expel women in cases of a sexual nature, and also young spectators. But since the Star Chamber went, trials in secret seem not to have taken place until authorised in 1920 .

37. It has been suggested by J. Rusbridger in a book still in proof on George Blake that the sentence represented one year for each agent betrayed by Blake, who was of course a British agent. In fact Parker simply multiplied the maximum sentence of fourteen years by three, making the sentences run consecutively.

38. See C. Andrew, Secret Service, p.496, noting that George Brown was so enraged by the unscrupulous behaviour of the executive which, to save face, tried to conceal the fact that Blake had been a British agent, that he leaked the information to Chapman Pincher (see his Inside Stony, Ch. 3 and C. Andrew's comments). 
all the Lord Chief Justice. Perhaps worse still is the case of Captain John King, a Foreign Office cypher clerk, apparently tried in camera at the Old Bailey on 18 October 1939 and sentenced after a plea of guilty to ten years imprisonment. ${ }^{39}$ The very fact that this trial had taken place at all was concealed for twenty years. ${ }^{40}$ Not much glasnost there. These are outrageous examples. But can anyone recall a case in which the judges resisted executive pressure for secrecy? I should not like to say that there have been no such cases, but certainly there have been none which have become leading cases on the matter. Or take telephone tapping. ${ }^{41}$ Apparently, until 1937 there was no formal control over this practice, but in that year the Home Office and Post Office got together and without of course telling anyone about it decided to establish a system whereby tapping was authorised by Home Secretary's warrant. ${ }^{42}$ At some point before the 1980s the Foreign Office also got into the act; tapping could be at the request either of the Security Service, the Foreign Office, the Customs service, or the regular police. The practice is common and I have personal information which makes it clear that the system of warrants is not in fact always observed, in the sense that methods which do not employ tapping by post office officials are used, which is as anyone not damp behind the ears would expect. It is so easy to bug a telephone, especially if you are a member of MI5 or Special Branch and in consequence in practice immune from interference from the police if found up a drainpipe clutching electronic equipment. The contributions made by judges to this practice have been considerable, but the contribution of the courts to the control of this practice has been, quite simply, nil. $^{43}$ But to be fair they have only really had one chance.

I could go on. But it is also true that there have been occasions when the decisions of the courts have incommoded the workings of the vigilant state. Let me give you two examples.

One took place in 1923. The emergency powers acquired by the executive during the first world war under DORA - the Defence of the Realm Acts - long survived the end of the fighting brought about by the Armistice of 1918. The war did not officially end then; as if four years was not enough it was prolonged by Act

39. Accounts of this case will be found in a number of books. N. West, MI5, p. 90, says that (as John Herbert King) he was tried before Hilbery J. on charges arising out of the Emergency Powers Act, after having confessed under the influence of alcohol. He is described as having been commissioned in the Artists Rifles, and that he was detected through information supplied by the defector Walter Krivitsky. C. Andrew, Secret Service, in a documented account (p. 432), based in part on the diaries of Sir Alexander Cadogan, suggests that King was subjected to "third degree" interrogation, whatever precisely that meant.

40. West has it that the story was released in 1956 .

41. One has to be careful over the concept of tapping. It is possible to overhear a telephone conversation in a variety of different ways, only some involving any direct connection with the line. There is also information to be gained from recording the duration and destination of calls, without overhearing them.

42. An account is given in the Birkett Report of 1957, Cmnd. 283.

43. See Malone v. Metropolitan Police Commissioner (No. 2) [1979] 2 All E.R. 620. A useful collection of references is provided by S. H. Bailey, D. J. Harris and B. L. Jones, Civil Liberties. Cases and Materials 2d. ed., pp. 381-392. 
of Parliament for a further three, that is until 31 August 1921. During this period there were, as ever, troubles in Ireland. But one might imagine that the official end of the war, coupled with the Anglo-Irish Treaty of 6 December 1921, together with the establishment of the Irish Free State, would have ended the practice of executive detention without term, charge or trial, in England, Wales and Scotland under the Restoration of Order in Ireland Act - the practice upheld in Brady's case. Not a bit of it. But it was held improper at last in R. v. Secretary of State for Home Affairs, Ex parte O'Brien decided in 1923, and thus stopped by court decision. ${ }^{44}$ Another example occurred in 1941, when one of the $1,84718 \mathrm{~B}$ detainees of the second world war, Captain Charles Henry Bentick Budd, was actually released by court order in habeas corpus proceedings, not on grounds of substance, but because of formal irregularity in his arrest. It did him no good since he was soon re-arrested, formal irregularity being easily cured, though he did enjoy a brief period of liberty in which he caught 'flu. The same fate of re-arrest overtook some other detainees whose situation was also formally irregular, and who enjoyed a brief freedom as a result of Budd's action whilst new documents were prepared. No doubt other examples might be given of decisions adverse to the vigilant state, but they do not affect the general picture in any significant way. ${ }^{45}$

Now let me try to provide an explanation for the phenomenon I have tried to illustrate: judicial passivity in the face of the vigilant state. Judicial passivity sounds rather disagreeable; let me make it clear that I am not attributing some sort of personal vice to individual members of the judiciary; I am really not concerned with individuals, and to explain this I must say something about that mysterious entity, "the law", which is supposed to control the behaviour of individual judges. There are people who will tell you that the law is a system of rules, or a system of rules and principles, and perhaps exceptions and definitions, but all that is, I am afraid, an ideal picture. That is what those who write treatises try to make it, like J. C. Gray, who, after a hundred and forty-odd pages of intricate text, took a deep breath and delivered himself of The Rule Against Perpetuities, which he had invented, together with the weird dogma that it was to be Remorselessly Applied, which meant without any commonsense or attention to purpose at all, and he got away with it. Mercifully few do; the law is all much more messy and confused than that, and in many areas you never know which way the cat will jump from one moment to the next. ${ }^{46}$ I prefer to think of "the law" as a professional culture, rooted in tradition, and comprising a whole range of beliefs and attitudes and ideals and values and practices and customs like wearing silly clothes and ways of

44. [1923] 2 K.B. 361; [1923] A.C. 603.

45. For discussion of Budd's case and references see my Rhetoric, Reality and Regulation $18 B$ (the Child \& Co. Lecture of Tuesday 12 May 1987) reprinted in 1988 Denning Lam Foumal, p. 123. There is some slight uncertainty as to whether all those released were re-arrested, but I think that all were. The principle source on Budd is PRO TS27/506. His first action is reported in The Times, 28 May 1941. 46. On all this see my The Common Law and Legal Theory, originally published in Oxford Essays in Furisprudence 2nd. Ser., pp. 77-99 and reprinted in Legal Theory and Legal Histon. Essays on the Common law (1987) and in W. L. Twining (ed.), Legal Theory and the Common Law (1987). 
analysing problems and happenings in the world and a language to talk about them in and even jokes about snails in bottles and, one must add, etcetera. The passivity I have mentioned is part of this culture, just as aggression is part of the special culture of the members of the Special Air Service, ${ }^{47}$ and to say this is merely to record what seems to be the case, whether we like it or not. Judicial behaviour does not have to conform to the culture, in the sense that it is perfectly possible for judges to act differently, just as I might have turned up for lectures wearing a bikini rather than a suit and tie, which is what professors are supposed to wear on such occasions, however hot the weather. But, like professors, judges will generally do what seems to be expected of them, and in doing so will of course conceive of themselves as doing the right thing, following "the law" if you will.

Now one explanation of judicial passivity could be pragmatic realism. Since Parliament is sovereign, or more or less so, and is commonly controlled by the executive, although so called back bench revolts occur from time to time, judicial decisions can always be reversed. So if the judges give decisions unfavourable to the executive the only result is that they are reversed by legislation (or, as in Budd's case, by administrative action). Hence it is futile for the courts to rock the boat, and the judges recognise reality in their decisions. This explanation assumes that the judges have no real power. I do not find this persuasive. In reality the executive does not, and politically often cannot simply reverse unpalatable decisions. The O'Brien case is an example. My own work on detention in the 1939-45 war convinces me that professional civil servants were at this time very nervous over possible defeats in the courts and risk of judicial criticism. What they feared was the political consequences of such defeats. Hence, for example, very great trouble was taken to defend actions brought by detainees vigorously, and to attempt to present the executive as doing its competent best in trying conditions.

The most dramatic illustration of this nervousness of the courts involved an individual called Arthur Campbell. ${ }^{48}$ An ex-soldier, possibly a little unbalanced, ${ }^{49}$ he had been a member of the British Union of Fascists until 1937. He was detained in June of 1940 as being "of hostile associations" on pathetically meagre grounds. He was entitled under the Defence Regulations to be told the reasons for his detention, and was informed officially, but wrongly, that he had been detained under a separate provision of Regulation $18 \mathrm{~B}^{50}$ as having been a member of the British Union of Fascists. He exercised his right to a hearing before the Advisory Committee, which reported in October and failed to notice the discrepancy

47. Not of course just the S.A.S. I spent many hours in my military training being schooled both in aggression and in how to make soldiers whom I commanded aggressive. Fortunately I never had occasion to practice these skills.

48. This account is based on PRO TS $27 / 507$ and HO 144/21635/840921, the latter file being much weeded. Not all papers are available. The Home Office, under the influence of MI5, continues to impede the writing of the history of the second world war.

49. Many first war soldiers were permanently unsettled by the terrible experiences of the trenches, and if one considers the conditions in which they fought this is hardly to be wondered at.

50. Regulation 18B was amended in May of 1940 in order to permit the locking up of Sir Oswald Mosley and many of his supporters under a provision known as 18B $1 \mathrm{~A}$. 
between the formal ground upon which he had in fact been detained, and the reasons given to him. The Committee ${ }^{51}$ recommended continued detention. He eventually started proceedings by way of habeas corpus, being represented by the liberal minded solicitor Oswald Hickson. These were pending when Captain Budd won his action.

Preparations were made to contest his application, but in the course of these Sir John Anderson signed an affidavit which revealed an extraordinary practice which had been established over 18B detainees and followed in hundreds of cases. The reasons which were supplied to detainees, as required by law, were prepared by officers of the Security Service, who did their best to guess why Sir John Anderson or his successor Herbert Morrison had ordered detention. They had to guess because, to put it simply, the Home Secretary never revealed why he had ordered detention. ${ }^{52}$ In the wake of the Budd case, and with knowledge of behind the scenes judicial criticism of the errors being made in the Home Office, Valentine Holmes, the Treasury Counsel handling the matter, advised that Arthur Campbell had better be released rather than reveal all this to the judges. His advice was followed. The civil servants did not relish getting judicial egg upon their shirts. ${ }^{53}$ The moral of this story is that the executive was not in any way indifferent to the views of the judges. Officials seem to have been rather frightened of them.

Another possibility is that the judges were simply callous. Well, there have always been judges who have been callous or become so. In my own experience, I recall being appalled by a fellow magistrate who, before going into the defaulters' court, said brightly to me, "Well, I hope we imprison someone today." I also recall another magistrate who, confronted with a rather defective person coming up for sentence, remarked "We could always send him to the vet." These are not remarks one ever forgets. But I do not myself think that as a general explanation callous indifference is plausible. ${ }^{54}$ Let me give you an example. In the summer of 1940 the scale of detention under regulation $18 \mathrm{~B}$ increased very sharply indeed. By the end of April of 1940 only 136 detention orders had been made, and only fifty-eight persons remained in custody. By the end of August the number in custody had risen to 1428 . This rise in the use of $18 \mathrm{~B}$ coincided with the mass detention of enemy aliens, most of whom were refugees from fascism. Something of the order of 28,000 of them were detained. To put these figures in perspective, the daily average prison population at this period was around 8,000 . Inevitably, this

51. The committee met in various panels; this one was presided over by A. W. Cockburn K.C..

52. One of the difficulties was that Sir John did not normally have any precise reasons; he went on the general impression gained from so much perusal of the minuted file as he was able to engage in. His minute on the file did not take the form of "I agree to detention for the following reasons" but rather "I agree."

53. I am afraid that it did him little good. A new order was made and he languished in detention until 1 July 1941. Civil actions for defamation and false imprisonment were abandoned; the combined effect of the legal decisions deprived such people of any hope of any sort of remedy in the courts:

54. This does not mean that some decisions were not influenced by an inability to sympathise with the predicament of others. 
all brought about very considerable administrative confusion. Now detainees had a right under the regulations to be told the grounds on which the order had been made, and be furnished with particulars; these were provided in a written document headed "Reasons for Order", which was provided to detainees some time after their arrest. They also had a right to put their case to an Advisory Committee, ${ }^{55}$ and of course needed the "Reasons for Order" in order to do this. One of the consequences of the great incarceration of the summer of 1940 was that considerable delays began to occur between the arrest of an individual, the provision of the "Reasons for Order", and the hearing before the Advisory Committee. Once the hearing did take place a report had to be written and this, together with a transcript of the hearing: was then considered by Home Office officials and eventually a decision was taken as to whether or not to accept the advice. It took some time for the file to make its stately way up the hierarchy of officials for all of them felt obliged to scribble some sort of observation on the docket. Sir John Anderson always did accept the recommendation of the Advisory Committee, but his successor Herbert Morrison did not, so the consideration of the report was not a formality.

In October of 1940 a group of five detainees, represented by the same Oswald Hickson, applied for habeas corpus; one was a very prominent individual, Admiral Sir Barry Domvile, who, together with his wife Alexandrina ${ }^{56}$. had been detained on $8 \mathrm{July}$, almost exactly three months before the application was made. None of the five had yet been told why they were detained, nor had they yet of course been before the Advisory Committee.

The basis of the application was that the excessive delay amounted to a denial of their legal rights under the Defence Regulations, so that their detention was in consequence unlawful. Although this was a perfectly reasonable argument it was not accepted by the Divisional Court. One is tempted to say that they lost, of course. But Lord Caldecote, who as Lord Chief Justice presided over the hearing, was well aware of the administrative confusion which existed, ${ }^{57}$ and seems to have felt rather guilty about the whole business. So behind the scenes he wrote a long letter to the Home Secretary, Herbert Morrison, "as a friend". I shall quote one passage:

I shall be very sorry indeed and I am sure you would be if hereafter it was thought that we had been a little callous about the conditions in which these persons have been interned. A great many of them richly deserve internment

55. This sat in several panels; the chairman of the whole institution was Sir Norman Birkett.

56. His son Compton was detained about the same time. The basic source is PRO TS27/491.

57. Although I cannot document this, I should not be surprised if he had a discreet word with Norman Birkett or one of the other lawyers involved with the Advisory Committee; in the incestuous little world of the London bar it would be easy to have found out what was happening. 
but a great many of them are wholly innocent and known to have the most friendly feelings towards this country. ${ }^{58}$

He offered to lend some judges to afforce the Advisory Committee and speed up its work, but this offer was turned down, one reason being that judges might not be easy about operating in a merely advisory role. Judges decide; it is not their role to advise. $^{59}$

If we reject both pragmatic realism and indifference as explanations for judicial reluctance to interfere with the growing power of the vigilant state, much less any sort of sinister conspiracy, what are we left with? I do not think that it is, in the nature of things, possible to provide either a simple explanation or one that can be conclusively demonstrated to be correct. What can perhaps be said is that judicial passivity in this area is related to certain ideas and attitudes which form part of our judicial and legal culture, and to certain institutional forms of behaviour.

I shall begin with ideas and attitudes. First, let me tell you about what I call the Reading principle or presumption. I so call it from a remark made by Lord Reading as Lord Chief Justice back in 1920 in a habeas corpus application on behalf of one Patrick Foy. ${ }^{60}$ He had been detained in Dublin on 14 January 1920 by an order made under Regulation 14B of the DORA regulations, as amended in 1918, on suspicion of engagement in "acts prejudicial to the public safety or the defence of the realm". He had been moved to Wormwood Scrubs Prison in London. Now the Peace Treaty with Germany had been signed on January 10, and one argument advanced for Patrick Foy by Sir John Simon, himself the father of executive detention, ${ }^{61}$ was this:

The whole of the Defence of the Realm legislation ... was directed to the protection of the country from foreign foes during the period of the war. It was not intended to be used for the suppression of rebellion or the preservation of internal order even during the war, and still less at a time when the war was over.

But the court was not impressed; the war was still officially in progress. ${ }^{62}$ In the course of his opinion, Lord Reading said this:

58. The letter appears to have involved concern over the detained aliens as well as detained citizens. it is in PRO HO 45/25114.

59. In fact Norman Birkett continued to run the Advisory Committee after he became a judge, but he had a happy relationship with the civil servants and caused them no anxieties. Other judges might have meant trouble.

60. [1920] 2 K.B. 305; 34 T.L.R. 7. See also PRO TS 27/85.

61. Sir John had, as Home Secretary, brought in Regulation 14B in 1915; in its original form it was presented as an extension of alien control, permitting the detention of persons of hostile origin or associations who, as citizens, could not be held under the prerogative.

62. It ended officially on 31 August 1921. 
It is of course always to be assumed that the executive will act honestly and that its powers will be reasonably exercised.

Contrast that, if you will, with the golden thread and Woolmington. Lord Reading's remark is, I think, a particularly clear statement of the attitude of mind with which the judiciary have approached the activities of the vigilant state, and it is an attitude of mind which has been in general reflected in the course of judicial decisions in this area. Indeed the Reading presumption recurs like a refrain in various forms in the cases, and its power is enormously enhanced by decisions which make it in practice impossible for citizens to discover whether the executive has in fact acted honestly and exercised its powers reasonably. In our field the classic decision here is Liversidge v. Anderson, which prevented detainees from prising out of the officials information vital to their case. Combine the Reading presumption with executive secrecy and you have a recipe for uncontrolled executive power. ${ }^{63}$

The second idea or attitude to which I draw attention is the British legal culture's theory of civil rights, known as the doctrine of the "fair" or "fundamental" balance. The fullest statement is to be found in the Report of the Royal Commission on Criminal Procedure of $1981,{ }^{64}$ but statements turn up all over the place. According to this theory a "fair" balance must be maintained between the rights of individuals and the public interest. Consequently, if some supposedly grave question of public importance is involved, and what could be graver than National Security, ${ }^{65}$ the rights of individuals go straight down the tubes. Hence the more you need rights, the less rights you have, because under this theory you are never allowed rights when they are a serious nuisance to the authorities. This is all built into our criminal procedure. If you are suspected of shop lifting and want a lawyer the telephone will usually be out of order for a while, but if you persist you will be allowed access. But if you are suspected of murdering children or planting bombs, and really do need a lawyer very badly indeed, your hopes of getting one are much reduced, the idea being to let you have a lawyer so long as it's too late to help. Imagine a medical system which delayed access to doctors for longer periods in cases of grave illness; that really would alter the structure of the waiting times and, the gravely ill having died, release resources to deal with trivial complaints.

Let me quote you as an example of the thinking involved the words of Lord Denning in The Family Stony. During the war Lord Denning was a legal adviser to

63. Curiously enough, a civil servant who attended the lecture told me that on the same day he had given advice in terms of the Reading presumption.

64. Cmnd. 8092, paras. 1.11-1.23. I have no idea why the report calls the balance "fundamental" unless the point is to add an air of plausibility to this pernicious notion. After all, if something is 'fundamental' one can hardly disagree with it. Or perhaps the use of 'fundamental' instead of 'fair' reflects a dim awareness that the one thing the balance is not is 'fair'.

65. It is not at all clear what is meant by this expression, but if it means the security of the country from foreign attack or domination most references to it are ridiculous. 
the North East Region; I quote extracts from his account of this work, couched in his celebrated pithy style:

Most of my work in Leeds was to detain people under Regulation 18B . . As an instance I would tell of the "Nazi parson" in a village in Yorkshire. $\mathrm{He}$ often spent his holidays in Germany ... Although there was no case against him, no proof at all, I detained him under $18 \mathrm{~B}^{66}$ The Bishop of Ripon protested, but we took no notice.

Only the effect of the British theory of rights could lead that great and good man to be able to write and publish this passage, and some unease is revealed by the fact that three lines later Lord Denning, presumably in an attempt to distance himself from all this, ${ }^{67}$ refers to Lord Atkin's dissent in the Liversidge case as "after my own heart". Let me make it clear that I quote this passage from Lord Denning merely to make the point that the theory of rights I have stated is so deeply embedded in our legal culture that even Lord Denning can write this passage. ${ }^{68}$

The third attitude is one of aversion to reality. Now law or legal culture provides us with a scheme for interpreting reality; as a lawyer passes through the checkout at the supermarket he knows that what is going on is not shopping for supper but offer and acceptance, and as he walks under a ladder he knows he is in the area of forseeable risk and is comforted by the existence of a duty to take care. Now one of the troubles about this aspect of legal culture is that it may form a complete barrier to the perception of reality. Legal concepts can entirely banish common sense, or conceal the absence of the Emperor's clothes. A good example is the famous case of D.P.P. v. Smith ${ }^{69}$ where the responsibility of the accused man for the terrible accident which killed the police officer was discussed in part in terms of the concept of "contemplation". Outside the gobbledegook of the law, contemplation is an activity more or less confined to the professed religious in enclosed orders, and of course was wholly irrelevant to understanding or categorising for legal purposes the actions of Smith who was, as he explained, at the time in a panic. Between the incident itself and the opinion of Lord Kilmuir a complete gulf existed; the legal concepts did not help, but got in the way. In the case of the vigilant state the same gulf seems to exist. Thus in the cases dealing with my

66. Not really. What happened was that a request was submitted on form DR8 via MI5 to the Home Office.

67. The passage argues that "this was the law", but of course it wasn't. Those who recall this period will know that in the summer of 1940 there were spies and saboteurs absolutely everywhere; a favourite activity was "signalling".

68. I have not yet certainly identified the Nazi parson; there were a number of parsons who were of the far right - the Revds. A. Palmer, E. C. Opie, M. Yate Allen, E. Roberts, G. Dymock and H. E. B. Nye. Having been brought up in the world of the vicarage, the existence of this form of dottiness amongst parsons comes as no surprise. The detention probably took place in 1940, that is before the law of detention was settled in its extreme form by the Lords' decisions of November 1941.

69. [1961] A.C. 290. 
detainees the picture is one in which the Home Secretary, Sir John Anderson or his successor, is presented as having given personal and careful attention to the decision to detain each individual, satisfying himself that he had reasonable cause to believe the person fell into a detainable category and needed to be detained - it is the way we expect a judge or member of a jury to behave. It was this care taken by a high officer of state that justified the passivity of the courts. In reality nothing of the sort took place. Even before things hotted up the Home Secretary never himself quizzed the agents of MI5 on whose word detentions took place, and only very rarely met with senior security officers at all. He merely looked at files and the minutes on them, no doubt occasionally chatting with his Permanent Under-Secretary on particular cases. In June 1940 Sir John made 826 detention orders, and at ten minutes per order the work of consideration would have filled 137 man-hours. Some names of detainees probably never even passed over his desk, and on at least one occasion Herbert Morrison signed detention orders in blank; some alarm arose when these were accidentally left behind in a pub before service. We are in a world where "lifting the veil" as they say in corporation law is regularly eschewed.

What of institutional practices? Back in the days of the classical common law, judges in their official capacity 'judged'. Of course they did other things - attended prize fights for example - but not as judges. Judging was their function in the scheme of things. But in the late nineteenth century they began to perform as judges on committees and tribunals of inquiry of one kind and another. An early example is the Commission of 1886 (Mr. Justice Day) to inquire into the Belfast riots; better kncwn is the Parnell Commission of $1888 ;^{70}$ one can hardly overestimate the pernicious effects of our unhappy relationship with Ireland on our legal situation. Since then the practice has become increasingly common; more recent examples include the Lynskey Tribunal of 1948-49 before which Robert Liversidge put in a cameo appearance, Lord Justice Parker on bank-rate leaks in 1957-58, Lord Radcliffe and Mr. Justice Barry on spies in 1962-63 and Lord Edmund Davies on Aberfan in 1966-1967. ${ }^{71}$ Then there has been Lord Scarman on the Brixton riots. ${ }^{72}$ Judges are used - let me emphasise the word 'used' - by the executive in cases of riots, scandals and disasters for a reason clearly set out in the evidence given by Sir Robert Armstrong, then Cabinet Secretary, in the Spycatcher case in Australia. ${ }^{73}$

70. This was established by a special Act, 51 \& 52 Vict.c.31, the judges being Sir James Hannen, Sir John Day and Sir Archibald Smith. The commission of inquiry replaced the use of Select Committees of the Commons; they also, in a sense, replace the regular processes of investigating and prosecuting crime.

71. See, generally, G. W. Keeton, Trial by Tribunal (London, 1960), G. Rhodes, Committees of Inquiny (London, 1972), F. L. Morrison, The Courts and the Political Process in England (London, 1973) and Cmnd. 3121 of 1966 (Lord Justic Salmon). For comment, see R. B. Stevens, "The Independence of the Judiciary: The View from the Lord Chancellor's Office", 8 Oxford 70. of Legal Studies 222 (1988). 72. A distinct phenomenon has been the use of judges as civil servants, for example on the siting of a new London airport.

73. Quoted in Colin Turnbull's account of the case at p. 62. 
Sir Robert was being asked whether the procedure followed by Lord Bridge of Harwich in investigating official telephone tapping in 1985 had been satisfactory. You will recall that Lord Bridge was asked the somewhat peculiar question whether all official phone taps in a defined period (1970-1984) had been properly authorised: whether authorised interceptions since 1970 had been approved by Ministers according to the rules. After a very brief and secret investigation of this wholly uninteresting question, and one that naturally did not detain him long, he reported that in all 6129 cases everything had been properly done, and published no reasons for this conclusion. Given the form of the question it is hard to see what other conclusion could have been reached. Counsel, in the person of Colin Turnbull, asked Sir Robert whether it was satisfactory:

for Lord Bridge to simply publish his conclusions and none of the facts upon which it was based?

Sir Robert, who presumably devoted his considerable talents as an obfuscator to drafting, or approving, both the terms of reference and the idea of this investigation, naturally enough did think it satisfactory, and replied:

Because it may not be possible to publish, to make public all the evidence on which the conclusions are based. And that being so, the purpose of having somebody of the independence and stature of Lord Bridge of Harwich is to assure the public that when it is not possible for reasons of national security to give reasons, somebody of that independence and stature has satisfied himself that this is right.

Note the concepts involved: stature and independence. ${ }^{74}$ What is involved is a form of parasitism; the political effectiveness of this technique of reassurance is parasitic upon the respect generated by the normal exercise of the judicial function, in which judges stand for things like independence from the executive, impartiality, respect for the rule of law, explicit justification of decisions (subject to appeal) after fair hearings of evidence presented in open court, with benefit of counsel. The trick is to transfer the respect thus gained to legitimate decisions reached in wholly different contexts, and through procedures wholly at odds with the ideal of the rule of law.

Such parasitism has a long history. In the first war the rights of detainees, insofar as they had any, were entrusted to an Advisory Committee run by two judges, Sir John Sankey and Sir Robert Younger. This body met in secret, allowed no legal representation, published no reports or reasons and allowed no confrontation of witnesses. Its procedures conformed to the popular image of the

74. Not to mention the impossibility of publishing all the evidence (so publish none) and national security (many taps have nothing whatever to do with national security). 
Star Chamber. In the second war much the same system was employed; Sir Norman Birkett, as we have seen, ran a similar body. He had, of course, great public stature as an advocate, and he continued to run the Committee after he became a judge. En passant let me make clear that it is my own opinion that he, and other lawyers who served as panel chairmen, did a great deal to protect British citizens from the excesses of MI5; absence of evidence makes it impossible to form any view about what happened in the first war. The parasitism I have described reached its ultimate in the inquiry into the Profumo scandal. Let me simply quote what Lord Justice Salmon ${ }^{75}$ said about it.

The Government decided that to allay the very widespread public concern an inquiry should be held. They decided however not to set up a Tribunal for this purpose under the Act of 1921; instead they appointed Lord Denning, the Master of the Rolls, to hold this inquiry. This task he performed with conspicuous success despite the difficulties inherent in the procedure which he followed. The inquiry was conducted behind closed doors. None of the witnesses heard any of the evidence given against him by others or had any opportunity of testing such evidence. The transcript of the evidence was never published. Lord Denning had in effect to act as detective, solicitor, counsel and judge. In spite of the many defects in the procedure Lord Dening's Report was generally accepted by the public. But this was only because of Lord Denning's rare qualities and high reputation. Even the public acceptance of the Report may be regarded as a brilliant exception to what would normally occur when an inquiry is carried out under such conditions.

It is I think not necessary to do more than quote this passage.

Now of course the judges who have allowed themselves to be used by the executive in this way have no doubt agreed to act from the highest motives, and done their best to do a good job, but their activities seem to me wholly incompatible with the conception of judicial independence from the executive which was established by the Glorious Revolution. Such work involves joining the executive, becoming pro tempore incorporated into the civil service, and in our area becoming part of the apparatus of that part of the executive which constitutes the secret and vigilant state. The very nature of these activities stands in direct opposition to the ideal of the rule of law. Judges, as it seems to me, should have absolutely nothing to do with secret hearings where there is no legal representation, no confrontation of witnesses, no giving of judgment in open court after a hearing in open court. Their involvement in such goings on may in the short term confer a spurious legitimacy on what is done, but they should para. 21. 
remember that parasites, though they do not destroy their hosts, ${ }^{76}$ always debilitate them, and what is involved here is the debilitation of the judicial function and ultimately the degradation of the judicial office. A particularly worrying feature of the whole process of incorporation into the vigilant state is that it possesses a seductive quality. Thus in the Profumo report there are passages extolling the positive advantages of the procedures involved. An extreme example is a memorandum written by Sir Norman Birkett in $1940^{77}$ explaining why the absence of legal representation before his committee did detainees no harm - yet Birkett's whole stature in society, the reason he was doing the job at all, had come about through his career as an advocate at the English bar. Nothing more clearly illustrates the incompatibility between the ideals of the common law and this sort of work. We all agree that there are things judges ought not to do; indeed documents emanate from the Lord Chancellor's Office telling them not to appear on television or whatever. These deal in silly trivialities; running secret enquiries is not a triviality.

Whether I persuade you of this or not, and I simply give you my opinion, I think that the blurring of roles involved in all this must have something to do with the phenomenon of judicial passivity in the face of the vigilant state. ${ }^{78}$

Now in recent times there has been much said about the need for a new Bill of Rights. I have here a recent piece by Lord Scarman, published in The Independent on 9 June $1989 .{ }^{79}$ One point he makes there is that such a Bill of Rights would have an educative function - he has in mind children being taught from it about "the values and principles of our free society". No doubt this is right, and I should suggest that such a Bill of Rights might also have a further educative function for lawyers. Its existence would, I think, modify our legal and judicial culture, and whatever precise form such a document took it would surely express ideals and values of a character which would make it extremely difficult, if not impossible, for judges committed to enforcing its provisions to join in activities wholly at odds with the ideals and values embodied in them. That would seem to me to be a good development, and one in keeping with the tradition of judicial independence established in the Glorious Revolution of 1688.

76. As a class, that is.

77. Memorandum of 10 January 1940 in $\mathrm{HO} 45 / 25754$, quoted in my earlier article.

78. I do not here go into the phenomenon of selecting judges who have in the past been involved in intelligence work to sit on committees of one kind and another dealing with the vigilant state.

79. "A Bill of Rights could become the conscience of the nation." 